\title{
Physical and financial participation of teaching hospitals in private care in São Paulo - Brasil
}

\author{
(D) Olímpio José Noqueira Viana Bittar ${ }^{1}$ \\ (iD Carolina Zanatta ${ }^{1}$ \\ Denato Ribeiro Nogueira Ferraz²
}

1. Secretaria da Saúde do Estado de São Paulo - São Paulo - SP, Brasil. 2. Programa de Pós-Graduação em Políticas Públicas - Universidade de Mogi das Cruzes - Mogi das Cruzes - SP, Brasil.

http://dx.doi.org/10.1590/1806-9282.66.6.806

\section{SUMMARY}

OBJECTIVE: To evaluate the physical and financial participation of private health insurance beneficiaries in the TH located in the State of Sao Paulo, regarding the care of Brazilian Unique Health System patients, in the year 2017.

METHODS: The research data were obtained from the System of Evaluation of the Teaching Hospitals (SAHE), of the State Department of Health of São Paulo (SES/SP).

RESULTS: It was observed that, on average, the TH analyzed provide 17\% of their operational vacancies for the Supplementary Health System, and that the financial return is better in the philanthropic ones.

CONCLUSIONS: The health care services provided by TH deserve to be deepened, evaluating the real advantages obtained in the provision of services, given that supplementary health care requires differentiated infrastructure, and mainly the knowledge of operational costs in order to stipulate the procedures' price.

KEYWORDS: Health management. Public health. Supplementary health. Hospitals, teaching. Financial management.

\section{INTRODUCTION}

The Brazilian Constitution of 1988 establishes the Single Health System (SUS) along with the Supplementary Health System (SS), regulated by the National Supplementary Health Agency (ANS), for assistance to Brazilians, having covered $25 \%$ of the 208.5 million population in 2018. The systems rely on a network of health units, with emphasis on teaching hospitals (THs), whose certification began in 2004 with the Interministerial Decree $\mathrm{N}^{\circ} 1,000^{1}$, which established an important process to differentiate hospital groups that, in addition to health care, also carry out research and teaching. The country currently has $204 \mathrm{TH}$ that are certified and under contracts, 52 of which are located in the state of São Paulo (ESP) ${ }^{2}$, of different legal formats: public (indirect and direct administration) and private (philanthropic and beneficent). Of all teaching hospitals in the ESP, 38 are general hospitals and 14 are specialized. They are all equally distributed in 14 of the 17 macroregions of health, being of different sizes and providing assistance to the SUS and the SS, especially in medium and high complexity cases (MAC). Of these, 32 hospitals are under state supervision and 20 under municipal supervision. Among them, 28 TH service not only SUS patients, but SS patients covered by Group Medicine, Medical Cooperative, Health Insurance, and Self-Management, in 
addition to the private health insurance plans of philanthropic entities.

It is a well-known fact that the financing of health care procedures by SUS is outdated regarding operational costs, which stimulates some hospitals to increase service to beneficiaries of private health insurance plans to cover the difference in costs in TH and reach solvency. This type of care is deserving of technical study to confirm its advantages. This phenomenon, known as double-door, is found also in Public and Private $\mathrm{TH}^{3-5}$.

To measure and compare are essential concepts in running a business, especially in healthcare units, whose activities are complex, complicated, highly disruptive, high risk and cost, with greater weight in $\mathrm{TH}$, where research and educational activities are inherent and whose influence deserve physical and financial quantification and qualification for due governance and institutional sustainability.

By teaching hospitals (TH) we mean: University Hospital of ownership or management of a public or private university, or bound to them by assignment of use or leasing arrangements, duly formalized; School Hospital, of ownership or management by single medical schools, public or private, or bound to them by assignment of use or leasing arrangements, duly formalized; Auxiliary Teaching Hospital, one that is not owned or managed by a university or medical school alone, which develop programs of in-service training, undergraduate or post-graduate studies in health, duly under contract with an institution of higher education, per the classification adopted by the Ministério da Educação ${ }^{6}$.

The State Department of Health of São Paulo (SESSP) also defined its own functional classification, comprising the actual University Hospitals, Specialized Hospitals, and Under-Contract or Bound Hospitals (owned by the universities) to health faculties; these last two can have both teaching hospitals and auxiliary teaching hospitals (Table 1).

Table 1 includes the specialties and the total of THs, in addition to the number of those under SS contracts. The $52 \mathrm{TH}$ represent $25.5 \%$ of the TH in the Country. The $28 \mathrm{TH}$ that service private health insurance plans represent $58.8 \%$ of the TH of the ESP.

Comparisons between health systems are complex, considering the number of intervening variables, as evidenced by Mossialos et al. ${ }^{7}$, such as the different types of funding, mechanisms for providing services, and the legal classifications of the units. In THs, there are differences in the specialties offered and, in a single case, there is no provision of outpatient services for SS patients. There are also differences in infrastructure, all of which are factors that affect the amount spent in the provision of care.

It is noteworthy that among the public TH managed by Social Organizations of Health (OSS), none had beds intended to SS patients by legal obligation. It is also important to mention that there have been legislative attempts to allow hospitals managed by OSS to provide $25 \%$ of their beds for beneficiaries of private health insurance plans, which were not consolidated,

TABLE 1. TEACHING HOSPITALS IN THE STATE OF SÃO PAULO BY LEGAL CLASSIFICATION, SPECIALTY, TOTAL, AND TH WITH SS CONTRACTS

\begin{tabular}{|c|c|c|c|c|}
\hline SES (and ME) Classification & Legal Classification & Specializations & Number & SS Contracts \\
\hline University Hospital & $\begin{array}{l}\text { Indirect administration and Foun- } \\
\text { dation* }\end{array}$ & General & 8 & 6 \\
\hline Specialized & & & 14 & 7 \\
\hline \multirow{6}{*}{$\begin{array}{l}\text { (School Hospitals and } \\
\text { Auxiliary Teaching Hospitals) }\end{array}$} & Social Organization & Oncology & 5 & 3 \\
\hline & Direct Administration (AD) & Maternity & 4 & 1 \\
\hline & Philanthropic & Cardiology & 2 & 2 \\
\hline & \multirow[t]{3}{*}{ Autonomous (A) } & Infectious Diseases & 1 & 0 \\
\hline & & Renal transplantation & 1 & 1 \\
\hline & & Rehabilitation Hospital & 1 & 0 \\
\hline Bound to/Under Contract with Faculties & & & 30 & 15 \\
\hline \multirow{4}{*}{$\begin{array}{l}\text { (School Hospitals and } \\
\text { Auxiliary Teaching Hospitals) }\end{array}$} & Social Organization & General & 5 & 0 \\
\hline & Pub. L. Foundation/(A)/AD** & General & 8 & 1 \\
\hline & Santa Casa & General & 7 & 6 \\
\hline & Other philanthropic organizations & General & 10 & 8 \\
\hline Total & & & 52 & 28 \\
\hline
\end{tabular}

${ }^{*}$ Private Legal Foundation ${ }^{* *}$ Public Legal Foundation, direct administration, and indirect administration 
such as State Law $n^{0} 1,131$ of 2010, which had its effects suspended ${ }^{8}$.

\section{OBJECTIVE}

Analyze the physical and financial participation of care provided to beneficiaries of private health insurance plans in TH of the ESP in comparison to SUS patients in 2018.

\section{METHODS}

The data used are from the Teaching Hospitals Evaluation System (SAHE) of SESSP and the Hospital Information System (SIH) of the Information Department of SUS (DATASUS), of the Ministry of Health.

The sample consisted of $23 \mathrm{THs}, 82.1 \%$ of the $28 \mathrm{TH}$ that met the informational requirements on services provided for the SS per SAHE, in 2019 (with data from 2018). Five of them did not meet the requirements, of which four are under Municipal Management and not under contract with the SESSP, but with the Municipal Health Departments. One of the clauses for SESSP contracts requires the provision of information by the hospitals. Those under municipal management that, without contractual obligation, submit data to the SAHE certainly do so because they value the importance of such information for the management of the system and/or due to the information they receive in return from the SESSP when they need it for the assessment and planning of health actions.

From the SAHE we retrieved the following variables about private health insurance plans: total annual revenue, total number of operational beds and those intended for SS, number of patients discharged, and subsidies from the ESP treasury for public and philanthropic hospitals. From the DATASUS we retrieved the following variables: number of HAA, annual values from SUS regarding hospitalizations of high and medium complexity cases (MAC) and strategic cases (FAEC), and the number of hospital discharges of SUS patients.

We established an indicator capable of comparing the funding of the system, i.e., the ratio between the revenue of private health insurance plans and the income from SUS divided by the number of discharges in the same year, using as the definition of discharge when a patient leaves the inpatient unit upon medical discharge (cured, with improved or unchanged health), by evasion, due to withdrawal from treatment, internal transfer, external transfer, or death ${ }^{9}$. (Revenue or SUS Income/number of discharges)

Donations, scholarships for professionals financed by the SESSP, sale of non-clinical services, parliamentary amendments, and revenue from financial markets were not incorporated. It should be emphasized that all nonprofit hospitals analyzed in this study are CEBAS (Charitable Entity of Social Assistance Certificate) certified, which in itself is an indirect source of revenue since it exempts the unit from paying certain charges or taxes. According to Law No. 12,101 of 2009, a hospital is CEBAS certified in the area of healthcare if it services SUS at a minimum $60 \%$ percentage, taking into account hospitalizations and outpatient visits.

The TH included in the study were: Hospitais das Clínicas da Faculdade de Medicina da Universidade de São Paulo, de Ribeirão Preto, de Botucatu e de Marília, Hospital São Paulo, Hospital de Base de São José do Rio Preto, Hospital Amaral Carvalho, Centro Infantil Boldrini, Instituto Dante Pazzanese de Cardiologia, Instituto do Coração da Faculdade de Medicina da Universidade de São Paulo, Hospital do Rim, Hospital e Maternidade Celso Pierro, Santa Casa de Araraquara, Santa Casa de Ribeirão Preto, Santa Casa de Franca, Santa Casa de Fernandópolis, Santa Casa de Limeira, Santa Casa de Santos, Hospital Universitário São Francisco, Hospital Padre Albino, Hospital São Vicente de Paula, Hospital Santa Lucinda, and Casa de Saúde Santa Marcelina. The hospitals are represented by letters.

The TH were divided, according to the SESSP classification, into three groups: six university hospitals (those belonging the universities of São Paulo), five specialized (represented by those linked to universities of São Paulo, philanthropic and of direct administration by the ESP), and 12 philanthropic (general hospitals such as Santas Casas and associations). In the specialized group, there are the Auxiliary Teaching Hospitals, and in the group of hospitals under contract, there are Teaching Hospitals and Auxiliary Teaching Hospitals, according to the MS/ME classification.

To analyze the information, we used descriptive statistics.

\section{RESULTS AND DISCUSSION}

The integration between the SUS and SS systems, considering a perspective of information and planning, organization, management, and evaluation of the health system as a whole, is highly desired, but 
aspects such as the use of public beds for SS clients and patients tend to decrease the supply of services to the population that depends on SUS.

In table 2, we present the University Hospitals, with a total of 4,215 beds, of which $11.0 \%$ are dedicated to the SS (12.9\% of SS discharges). These hospitals account for $11.4 \%$ to $22.9 \%$ of high-complexity hospitalizations.

It is possible to see that University Hospitals have little financial gain from servicing SS contracts, and the amounts received per discharge vary between 0.6 to 2.8 times what is refunded by the health insurance plans. University hospitals $\mathrm{G}$ and $\mathrm{M}$ are best paid by the SUS than by the SS. With the exception of the letter C TH, which provides $32.4 \%$ of its beds for the SS, the others do not provide more than $8.7 \%$.

The budgetary sources of these hospitals are the resources provided directly by the Ministry of Health and the ESP treasury.

Table 3 contains information on the five specialized
TH that service patients covered by the SS; the percentage of high-complexity hospitalizations varies from $30.7 \%$ to $88.1 \%$.

Of the 1,387 beds offered, $15.3 \%$ are destined to SS contracts, whose percentage of discharges is $16.4 \%$.

The gain from SS contracts presents greater uniformity when analyzed together, ranging from 1.6 to 3.3 times the value paid by SUS. No TH receives a lower amount from health insurance plans than that paid by SUS. This group contains both public hospitals with direct administration and autonomous philanthropic hospitals, except for the hospital of letter B, which provides only $4.2 \%$ of its beds to the SS; in all others, the percentage is higher, up to $29.9 \%$.

The specialized TH perform a greater number of high-complexity procedures, which are, therefore, of high complexity and costs, but offer a smaller number of specialties, thus enabling a more rational administration, although with all the difficulties inherent to hospitals.

TABLE 2. SS BEDS; TOTALS; SS/SUS RATIO; SS, SUS, TOTAL, AND DISCHARGES; SS/SUS DISCHARGE RATIO; REVENUE/SUS INCOME COMPARISON RATIO SS/SUS FOR SS AND SUS - UNIVERSITY HOSPITALS IN 2018

\begin{tabular}{|c|c|c|c|c|c|c|c|c|c|c|}
\hline University & $\begin{array}{l}\text { SS } \\
\text { Beds }\end{array}$ & $\begin{array}{l}\text { Total } \\
\text { Beds }\end{array}$ & $\begin{array}{l}\% \text { SS/ } \\
\text { SUS Beds }\end{array}$ & $\begin{array}{l}\text { SS Dis- } \\
\text { charges }\end{array}$ & $\begin{array}{l}\text { SUS Dis- } \\
\text { charges }\end{array}$ & $\begin{array}{l}\text { Total Discharges } \\
\text { SS + SUS }\end{array}$ & $\begin{array}{l}\% \text { Discharge } \\
\text { SS/SUS }\end{array}$ & $\begin{array}{l}\text { SS Revenue/ } \\
\text { SS Discharges }\end{array}$ & $\begin{array}{l}\text { SUS Income/ } \\
\text { SUS Discharges }\end{array}$ & SS/SUS \\
\hline C & 295 & 910 & 32.4 & 18,166 & 41,013 & 59,179 & 30.7 & $9,520.65$ & $8,397.00$ & 1.1 \\
\hline$E$ & 50 & 575 & 8.7 & 1,223 & 19,902 & 21,125 & 5.8 & $12,376.12$ & $10,182.86$ & 1.2 \\
\hline M & 69 & 1,223 & 5.6 & 5,398 & 50,709 & 56,107 & 9.6 & $(20,875.71)$ & $30,040.46$ & $(0.7)$ \\
\hline $\mathrm{H}$ & 38 & 759 & 5.0 & 889 & 38,128 & 39,017 & 2.3 & $55,025.27$ & $19,665.66$ & 2.8 \\
\hline$G$ & 10 & 524 & 1.9 & 1,309 & 25,249 & 26,558 & 4.9 & $(8,223.49)$ & $13,364.51$ & $(0.6)$ \\
\hline S & 6 & 224 & 2.7 & 163 & 8,011 & 8,174 & 2.0 & $17,838.46$ & $12,302.11$ & 1.5 \\
\hline $\begin{array}{l}\text { Subtotal/ } \\
\text { perc/ratio }\end{array}$ & 464 & 4,215 & 11.0 & 27,148 & 183,012 & 210,160 & 12.9 & $20,643.28$ & $15,658.77$ & 1.3 \\
\hline
\end{tabular}

TABLE 3. SS BEDS; TOTALS; SS/SUS RATIO; SS, SUS, TOTAL, AND DISCHARGES; SS/SUS DISCHARGE RATIO; REVENUE/SUS INCOME COMPARISON RATIO SS/SUS FOR SS AND SUS - SPECIALIZED HOSPITALS IN 2018

\begin{tabular}{|c|c|c|c|c|c|c|c|c|c|c|}
\hline Specialized & $\begin{array}{l}\text { SS } \\
\text { Beds }\end{array}$ & $\begin{array}{l}\text { Total } \\
\text { Beds }\end{array}$ & $\begin{array}{l}\% \text { SS/ } \\
\text { SUS Beds }\end{array}$ & $\begin{array}{l}\text { SS Dis- } \\
\text { charges }\end{array}$ & $\begin{array}{l}\text { SUS Dis- } \\
\text { charges }\end{array}$ & $\begin{array}{l}\text { Total Discharges } \\
\text { SS + SUS }\end{array}$ & $\begin{array}{l}\% \text { Discharge } \\
\text { SS/SUS }\end{array}$ & $\begin{array}{l}\text { SS Revenue/ } \\
\text { SS Discharges }\end{array}$ & $\begin{array}{l}\text { SUS Income/ } \\
\text { SUS Discharges }\end{array}$ & $\begin{array}{l}\$ \\
\text { SS/SUS }\end{array}$ \\
\hline$K$ & 80 & 380 & 21.1 & 3,682 & 12,460 & 16,142 & 22.8 & $23,607.91$ & $9,026.86$ & 2.6 \\
\hline AT & 23 & 77 & 29.9 & 971 & 2,575 & 3,546 & 27.4 & $17,700.90$ & $10,526.18$ & 1.7 \\
\hline B & 16 & 379 & 4.2 & 158 & 9,323 & 9,481 & 1.7 & $46,249.90$ & $24,779.27$ & 1.9 \\
\hline A & 73 & 400 & 18.3 & 2,557 & 11,914 & 14,471 & 17.7 & $51,251.80$ & $31,505.11$ & 1.6 \\
\hline$A C$ & 20 & 151 & 13.2 & 1,213 & 7,355 & 8,568 & 14.2 & $40,113.40$ & $12,054.42$ & 3.3 \\
\hline $\begin{array}{l}\text { Subtotal/ } \\
\text { perc/ratio }\end{array}$ & 212 & 1,387 & 15.3 & 8,581 & 43,627 & 52,208 & 16.4 & $33,927.02$ & $17,578.37$ & 1.9 \\
\hline
\end{tabular}


TABLE 4. SS BEDS; TOTALS; SS/SUS RATIO; SS, SUS, TOTAL, AND DISCHARGES; SS/SUS DISCHARGE RATIO; REVENUE/SUS INCOME COMPARISON RATIO SS/SUS FOR SS AND SUS - UNDER-CONTRACT OR BOUND HOSPITALS IN 2018

\begin{tabular}{|c|c|c|c|c|c|c|c|c|c|c|}
\hline $\begin{array}{l}\text { Under- } \\
\text { Contract }\end{array}$ & $\begin{array}{l}\text { SS } \\
\text { Beds }\end{array}$ & $\begin{array}{l}\text { Total } \\
\text { Beds }\end{array}$ & $\begin{array}{l}\% \text { SS/SUS } \\
\text { Beds }\end{array}$ & $\begin{array}{l}\text { SS Dis- } \\
\text { charges }\end{array}$ & $\begin{array}{l}\text { SUS Dis- } \\
\text { charges }\end{array}$ & $\begin{array}{l}\text { Total Discharges } \\
\text { SS + SUS }\end{array}$ & $\begin{array}{l}\% \text { Discharge } \\
\text { SS/SUS }\end{array}$ & $\begin{array}{l}\text { SS Revenue/ } \\
\text { SS Discharges }\end{array}$ & $\begin{array}{l}\text { SUS Income/ } \\
\text { SUS Discharges }\end{array}$ & $\begin{array}{l}\text { \$ } \\
\text { SS/SUS }\end{array}$ \\
\hline $\mathrm{BI}$ & 30 & 290 & 10.3 & 749 & 19,001 & 19,750 & 3.8 & $18,671.38$ & $5,767.45$ & 3,2 \\
\hline Y & 43 & 227 & 18.9 & 2,921 & 10,978 & 13,899 & 21.0 & $13,901.00$ & $5,967.44$ & 2,3 \\
\hline$B F$ & 32 & 116 & 27.6 & 1,298 & 5,048 & 6,346 & 20.5 & $6,546.95$ & $4,903.34$ & 1,3 \\
\hline AF & 327 & 664 & 49.2 & 11,752 & 11,116 & 22,868 & 51.4 & $33,367.73$ & $4,826.97$ & 6,9 \\
\hline $\mathrm{Al}$ & 91 & 254 & 35.8 & 4,332 & 12,214 & 16,546 & 26.2 & $18,226.73$ & 3,206.23 & 5,7 \\
\hline $\mathrm{BE}$ & 42 & 197 & 21.3 & 2,154 & 8,968 & 11,122 & 19.4 & $12,601.77$ & $5,157.04$ & 2,4 \\
\hline$A D$ & 141 & 726 & 19.4 & 7,042 & 26,410 & 33,452 & 21.1 & $34,332.95$ & $8,486.62$ & 4,0 \\
\hline$A B$ & 123 & 319 & 38.6 & 10,253 & 14,199 & 24,452 & 41.9 & $(8,326.20)$ & $12,295.67$ & $(0,7)$ \\
\hline$P$ & 76 & 226 & 33.6 & 3,369 & 9,680 & 13,049 & 25.8 & $11,855.29$ & $6,613.55$ & 1,8 \\
\hline AJ & 68 & 160 & 42.5 & 4,464 & 7,663 & 12,127 & 36.8 & $(4,242.66)$ & $4,456.08$ & $(0,9)$ \\
\hline$L$ & 67 & 198 & 33.8 & 3,892 & 8,721 & 12,613 & 30.9 & $(6,955.34)$ & $7,601.46$ & $(0,9)$ \\
\hline$A G$ & 6 & 238 & 2.5 & 146 & 16,115 & 16,261 & 0.9 & $16,043.77$ & $3,767.27$ & 4,3 \\
\hline $\begin{array}{l}\text { Subtotal/ } \\
\text { perc/ratio }\end{array}$ & 1,046 & 3,615 & 28.9 & 52,372 & 150.113 & 202,485 & 25.9 & $15,422.65$ & $6,087.43$ & 2,5 \\
\hline $\begin{array}{l}\text { Total/ } \\
\text { percentage/ } \\
\text { ratio }\end{array}$ & 1,722 & 9,141 & 18.7 & 88,101 & 376,752 & 464,853 & 19.0 & $23,331.00$ & $13,108.19$ & 1,8 \\
\hline
\end{tabular}

Table 4 presents the most heterogeneous group of THs, with 12 hospitals in which high-complexity hospitalizations range from $1.7 \%$ to $19.0 \%$.

This is the TH group with the greatest number of beds dedicated to the SS, i.e., $28.9 \%$, with $25.9 \%$ of discharges, that is, a quarter of their services are provided for the SS.

The financial gain from the SS, in comparison with that from SUS, is of a magnitude that ranges from 0.7 to 6.9 times, and three of the TH receive from SS contracts values lower than from the SUS.

The TH whose most significant source of funding is the SUS faces difficulties since the amounts paid for the procedures listed in the SUS Table have been outdated for years, with no other financial solution than to increase the number of beds destined for SS patients. These TH do not receive budgetary resources from the Treasury, although some do receive some type of subsidy. Only one of them provides $2.5 \%$ of its beds, all the other provide over $10.3 \%$, and the $\mathrm{TH}$ referred to by the AF acronym provides up to $49.2 \%$ of its beds for the SS.

On average, the three groups provide $18.7 \%$ of their beds for SS patients and are responsible for $19.0 \%$ of all discharges, although the average gain is 1.8 times that of SS on in comparison to the SUS.

Thus, the analysis of each individual group (university, specialized, and philanthropic hospitals) shows a better financial gain in philanthropic TH that service the SS.

\section{CONCLUSIONS}

After comparing the amounts received per discharge, although in two groups the gains from the SS were better, there are not enough indicators to establish the cost/benefit of this practice.

It is necessary to know the local and regional geographical, demographic, socioeconomic, and epidemiological conditions to verify the concrete need for the beds in both populations, i.e., SS and SUS.

The study shows that the decision of allocating a particular percentage of beds for the SS and SUS is not supported in technical and management tools. The decision to invest in increased supply for the SS is not a good solution for all cases; there is no evidence regarding the relationship between the different investments in the differentiation of services. 


\section{RESUMO}

OBJETIVO: Avaliar a participação física e financeira do atendimento aos beneficiários de planos privados de saúde nos Hospitais de Ensino (HE) do Estado de São Paulo (ESP), em relação ao atendimento a pacientes do Sistema Único de Saúde, no ano de 2018.

MÉTODOS: os dados da pesquisa foram obtidos do Sistema de Avaliação dos Hospitais de Ensino (SAHE), da Secretaria de Estado da Saúde do Estado de São Paulo e do Departamento de Informática do SUS (DATASUS) do Ministério da Saúde.

RESULTADOS: observou-se que, em média os HE analisados ofertam 18,7\% dos leitos operacionais para a Saúde Suplementar (SS), e que o retorno financeiro é melhor nos filantrópicos.

CONCLUSÕES: o atendimento a planos de saúde pelos HE merece ser aprofundado, avaliando-se as reais vantagens obtidas na prestação dos serviços e que o atendimento à SS exige infraestrutura diferenciada, e, principalmente o conhecimento de custos operacionais para estipulação de preços dos procedimentos.

PALAVRAS-ChaVe: Gestão em saúde. Saúde pública. Saúde suplementar. Hospitais de ensino. Administração financeira.

\section{REFERENCES}

1. Brasil. Ministério da Educação. Portaria Interministerial nº 1.000 , de 15 de abril de 2004. Art. $1^{\circ}$ Certificar como hospital de ensino as instituições hospitalares que servirem de campo para prática de atividades curriculares na área da saúde, sejam hospitais gerais e, ou especializados, de propriedade de instituição de ensino superior, pública ou privada, ou, ainda, formalmente conveniados com instituição de ensino superior. $\mathrm{n}^{\circ} 73$ - DOU de 16/04/04 - seção 1 - p. 13. Brasília: Ministério da Educação; 2004.

2. Brasil. Ministério da Saúde, Ministério da Educação. Portaria Interministerial n 3.960, de 31/12/2019 publicada D.O.U de 02/01/2020. Altera, para 31 de dezembro de 2019, o prazo fixado para validade da certificação de unidades hospitalares como hospitais de ensino. Brasília: Ministério da Saúde, Ministério da Educação; 2020.

3. Cohn A, Elias PE, lanni AMZ. "Subsídio cruzado" ou "dupla porta": o público e o privado no Hospital das Clínicas de São Paulo. Série Didática n ${ }^{\circ} 6$ - abri 2002. [cited 2020 Jan 5]. Available from: http://www.cedec.org.br/files_pdf/ DIDATI6-HC.pdf

4. Silva HP, Caxias MCL. Benefícios para alguns, prejuízos para muitos: razões e implicações da adoção da dupla porta de entrada em hospitais universitários. Saúde Soc. 2016;25(3):808-20.
5. Teixeira MF, Patrício RG. O fenômeno da "fila dupla" ou "segunda porta" no Sistema Único de Saúde e a inobservância ao princípio da impessoalidade: um exercício de aproximação de conceitos. Rev Direito Sanitário. 2011;11(3):50-62.

6. Brasil. Ministério da Educação. Portaria MEC n॰ 375 publicada no D.O.U. 04/03/1991 - "Estabelece conceituação de hospitais de ensino no País". Brasília: Ministério da Educação; 1991.

7. Mossialos E, Wenzl M, Osborn R, Sarnak D. International profiles of health care systems, 2015. New York: The Commonwealth Fund; 2016.

8. Bittar OJNV. Instrumentos gerenciais para tornar eficiente o financiamento dos hospitais de ensino. Rev Administração em Saúde. 2002;5(17):9-18.

9. Brasil. Ministério da Saúde. Secretaria de Assistência à Saúde. Padronização da nomenclatura do censo hospitalar. Série A. Normas e manuais técnicos. $2^{a}$ ed. revista. Brasília: Ministério da Saúde; 2002. Authors' contributions: The authors Olímpio José Nogueira Bittar, Carolina Zanatta, and Renato Ribeiro Nogueira Ferraz contributed equally to the concept, data collection, drafting, and final revision of the manuscript. 